\title{
SOCIO-ECONOMIC FACTORS INFLUENCING THE DEVELOPMENT OF RENEWABLE ENERGY PRODUCTION SECTOR IN POLAND
}

\section{Tadeusz A. Grzeszczyk ${ }^{1}$, Waldemar Izdebski², Michał Izdebski', Tadeusz Waściński ${ }^{4}$}

\footnotetext{
1 Warsaw University of Technology, Faculty of Management, Poland, ORCID: 0000-0002-4898-1931, tadeusz.grzeszczyk@pw.edu.pl;

2 Warsaw University of Technology, Faculty of Management, Poland, ORCID: 0000-0001-8790-515X, waldemar.izdebski@pw.edu.pl;

3 Warsaw University of Technology, Faculty of Management, Poland, ORCID: 0000-0002-6050-2833, izdebo@gmail.com;

4 Warsaw University of Technology, Faculty of Management, Poland, ORCID: 0000-0002-4848-314X, tadeusz.wascinski@pw.edu.pl.
}

\begin{abstract}
Poland is not one of the leaders in the use of renewable energy sources (RES), and most energy is still produced using hard coal and lignite. Therefore, there are noteworthy emissions of air pollution (including ashes and greenhouse gases), and the Polish energy sector is characterized by a substantial degree of carbonization, which, as a result, threatens to expressively increase the costs of electricity production, leading to financial penalties imposed by the EU. The aim of this paper is to analyze socio-economic factors influencing the development of the RES sector in Poland. According to this aim, expert research was carried out, in which the factors influencing development potential of RES were assessed at two levels (level II - 5 factors, level III - 15 factors) according to the factor tree analysis. Based on the analysis of the level II factors, it can be concluded that the development of the RES sector in Poland will depend to a decisive extent on factors such as: EU decisions and Polish legislation affecting the development of the RES sector in Poland, prices and availability of conventional energy carriers. Other two factors - regional policy on ecology and ecological awareness in Poland - have so far little impact on the development of this sector in the state. The analysis of the level III factors shows that the greatest impact on the development of the RES sector in Poland is the influence of European lobbying of manufacturers of machinery and equipment for renewable energy production on EU law, the impact of Polish lobbying of conventional energy producers on Polish law in the production of renewable energy and the influence of European lobbying of renewable energy producers into EU law.
\end{abstract}

Keywords: Renewable Energy Sources (RES), renewable energy economics, development of RES in Poland, RES investment conditions, socio-economic factors.

JEL Classification: G11, O21, Q28, Q54.

APA Style Citation: Grzeszczyk, T. A., Izdebski, W., Izdebski, M., \& Wascinski, T. (2021). Socio-economic Factors Influencing the Development of Renewable Energy Production Sector in Poland. E\&M Economics and Management, 24(1), 38-54. https://doi.org/10.15240/ tul/001/2021-1-003

\section{Introduction}

The EU policy is largely shaped by the idea of sustainable development, which is based on the assumption of satisfying the developmental aspirations of the present generation in such a way as to enable the next generations to achieve the same aspirations (Brundtland, 1987). For economists, the suitable way to sharpen this idea is to consider the various resources (including renewable and nonrenewable natural resources) that communities hold at any particular time. 
Resources passed to future generations should be comparable (in terms of the ability to provide an adequate standard of living) with the stocks inherited by their ancestors (Streimikiene \& Mikalauskiene, 2016).

Within the EU strategic objectives to ensure the implementation of this idea are, among others: reduction of greenhouse gas emissions by $20 \%$ till 2020 (compared to the level of 1990 ), increase of up to $20 \%$ share of energy from renewable energy sources (RES) in total energy consumption and increase of energy efficiency by $20 \%$. United Nations stated in 2015 that according to sustainable development goals, one of them is to provide everyone with access to sustainable, affordable, reliable and modern energy, which is expected to be achieved by 2030 (United Nations, 2015). Significant progress can be made in implementing this goal globally, but there is still a need to focus on improving access to clean and safe fuels, modern technologies and, above all, expanding the use of renewable energy (United Nations, 2019).

Developing the RES is conducive to meeting ambitious EU targets of climate and energy policies. Among these basic targets is to achieve total decarbonization of the economy by 2050 according to the 'European Green Deal' (Spencer et al., 2017) and EU long-term budget 2021-2027 is to be strongly linked with main climate targets (European Council, 2020). Some analyzes indicate that in the first half of 2020 , for the first time in the EU, more electricity was generated from renewable sources compared to fossil fuels $(40 \%$ of the EU-27's electricity - wind, hydro, solar and bioenergy were generated, whereas fossil fuels only 34\%) (EMBER, 2020), but not all 27 countries belonging to the Community are making sufficient efforts in this regard. Identification of socio-economic factors influencing the development of renewable energy production sectors in individual countries could be support for them. Literature study shows that also research concerning econometric models taking into account in a mathematical, multifaceted and objective way many economic, social, political and technical factors as well as contributing to the implementation of renewable energy, have great potential to support decision makers dealing with conversion of general strategic guidelines for specific economic, environmental and social policies (Quintana-Rojo et al., 2020).
The use of RES is one of the most dynamically developing branches of energy industry in the EU, including Poland, in recent years. Fossil fuels, which are the basis of the largest volume of energy produced, are limited in quantity, and their continuous exploitation leads to a reduction in their stocks. RES occur in the natural environment in various forms, e.g. biogas, wind blowing, solar radiation, flowing water and sea waves, and are used for producing electricity. Other sources, such as biomass or geothermal sources are used to produce heat. Theoretically, renewable sources are vast. While sources of wind, flowing water, solar radiation, geothermal, ocean waves and tides can be counted as infinitely large sources, the energy harvested from renewable or combined fuels can be classified as limited to some extent. Energy generated from the combustion of biomass, biogas or biofuels is classified as renewable energy although these fuels are incinerated in the energy production process and require continuous production.

Effective efforts should be made to significantly reduce the level of pollution and greenhouse gases emissions, increase renewable energy production, improve energy efficiency as well as strengthen competitiveness, economic growth and regional development (Myšáková et al., 2016). Poland is not one of the leaders in the use of RES, and most energy is still produced using hard coal and lignite. In this state, use of these fossil fuels for energy production is decreasing but remains high at around $60 \%$ and apart from that coal reserves are limited (Nilsson et al., 2006). Therefore, there are noteworthy emissions of air pollution (including ashes and greenhouse gases), and the Polish energy sector is characterized by a substantial degree of carbonization, which, as a result, threatens to expressively increase the costs of electricity production, leading to financial penalties imposed by the EU.

Pursuant to the European Parliament and Council Directive No. 2009/28/EC Poland, a member of the EU, undertook to achieve a gross final energy consumption ratio of at least $15 \%$ using renewable sources by 2020 (which has not been achieved). It is also worth noting that this indicator includes the gross consumption of electricity, gross energy in heating and cooling as well as in transport. An essential EU Energy Roadmap 2050 document underlines the importance of RES in the context 
of preventing excessive climate change caused by overproduction and emissions of greenhouse gases (European Commission, 2012). RES are also clearly visible in other strategic documents on the use of different energy sources and climate change. Climate and energy frameworks for 2020 and 2030 assume significant improvements in energy efficiency and a noticeable reduction in greenhouse gases emissions (Duscha et al., 2016).

Motivations underlining this research are both theoretical and practical. From the technical point of view, ensuring access to electricity is not a difficult task. Key importance is paid to socio-economic perspectives (including three edges of the so-called sustainable development triangle), i.e. for example economic sustainability (sustainable business models), distributional issues (the right to electricity) and environmental issues regarding $\mathrm{CO} 2$ as well as local, regional, and global pollution, and impact on public health (Karplus \& Von Hirschhausen, 2019).

Increasing the use of RES and continuous improvement of energy efficiency can lead to achieving greenhouse gases emission reduction under EU targets. A literature study indicates that there is a lack of research on the identification and analysis of socio-economic factors influencing the sustainable energy development. There are studies on sustainable energy development indicators and multicriteria decision making techniques that can support the processes of assessing energy policies, as well as estimating levels of implementation of energy policy targets in Baltic Sea Region countries that includes EU countries such as Germany, Poland, Denmark, Sweden, Finland and the three Baltic States countries, as well as other neighboring countries - Norway and Russia (Siksnelyte et al., 2019).
The aim of this paper is to analyze socioeconomic factors influencing the development of the RES sector in Poland. The authors of this paper also undertook analyzes of social and economic conditions of the development of this sector resulting from the binding regulations. They considered it necessary to conduct an analysis of the volume of electricity production using renewable sources in Poland and the $E U$, and then identify key factors affecting the development of this sector in the state. The results of the analysis can significantly contribute to the development of the RES sector in this country. The conducted study was to help to answer the following research questions:

- What were the volumes of electricity production using renewable sources in Poland and the EU?

- What are the key factors (e.g. economic and social) affecting the development of the renewable energy sector in Poland?

\section{Size of Primary Energy Obtained from RES in Poland and in the EU}

It is easy to see the downward trend of primary energy production in the EU countries in the years 2010-2014 (Tab. 1). This is caused by the problems with supplies of raw materials used for primary energy production, as well as the increasing costs of operation of infrastructure used to obtain fossil fuels. These costs may be related to the legislation and strategy adopted by the EU countries. This situation is different in Poland, where in the case of primary energy production, there is an upward trend from 2010 to 2013, with a production decline by around 5\% in 2014 .

The share of primary energy recovered from RES in 2010-2014 shows an upward trend, both in the EU (25.5\%) and in Poland (11.9\%). Comparing 2010 and 2014, the

Tab. 1: Primary energy acquisition in the EU and Poland in 2010-2014

\begin{tabular}{l|r|r|r|r|r}
\hline Acquisition of energy in the EU and Poland & $\mathbf{2 0 1 0}$ & $\mathbf{2 0 1 1}$ & $\mathbf{2 0 1 2}$ & $\mathbf{2 0 1 3}$ & $\mathbf{2 0 1 4}$ \\
\hline Acquisition of primary energy in the EU [Mtoe] & 835.8 & 802.2 & 795.3 & 790.5 & 770.7 \\
\hline Acquisition of primary energy in Poland [Mtoe] & 67.5 & 68.8 & 72.6 & 71.8 & 68.2 \\
\hline $\begin{array}{l}\text { Share of RES energy in primary EU energy } \\
\text { [\% of increase year to year] }\end{array}$ & 20.1 & 20.5 & 22.7 & 24.4 & 25.4 \\
\hline $\begin{array}{l}\text { Share of RES energy in primary in Poland } \\
\text { [\% of increase year to year] }\end{array}$ & 10.2 & 10.9 & 11.7 & 11.9 & 11.9 \\
\hline
\end{tabular}


Primary energy acquisition and share of RES in Poland in 2011-2015

\begin{tabular}{l|c|c|c|c|c}
\multicolumn{1}{c|}{$\begin{array}{c}\text { Share of RES } \\
\text { in primary energy }\end{array}$} & $\mathbf{2 0 1 1}$ & $\mathbf{2 0 1 2}$ & $\mathbf{2 0 1 3}$ & $\mathbf{2 0 1 4}$ & $\mathbf{2 0 1 5}$ \\
\hline $\begin{array}{l}\text { Primary energy } \\
\text { acquisition in Poland [TJ] }\end{array}$ & $2,882,363$ & $3,038,921$ & $3,006,461$ & $2,853,825$ & $2,869,751$ \\
\hline Share of RES [TJ] & 313,202 & 356,474 & 358,337 & 339,810 & 363,390 \\
\hline Share of RES [\%] & 10.9 & 11.7 & 11.9 & 11.9 & 12.7 \\
\hline
\end{tabular}

Source: based on Central Statistical Office (2015)

share of primary energy production in the EU increased by $5.3 \%$. By analyzing analogous data for Poland, it should be noted that the upward trend is not that high and stands at $1.7 \%$ for the same period.

Tab. 2 shows the amount of primary energy produced and the share of RES in this process in Poland in 2011-2015.

It is easy to see that the value of primary energy acquired does not differ significantly in 2011 and 2015. However, if we take into account the increase in primary energy (percentage) production from renewable sources - from $10.9 \%$ in 2010 to $12.7 \%$ in 2015 , with a similar level of primary energy production, it is easy to note that the volume of primary energy production increased from 313,202 TJ in 2010 to $363,390 \mathrm{TJ}$ in 2015 - volume growth of $16 \%$ over the years 2011-2015. The above values show the slightly growing trend in the volume of primary energy obtained using RES.

Tab. 3 shows the share of individual RES carriers in primary energy acquisition in 20112015 in Poland.
It is worth noting that the largest volume of primary energy is generated using the combustion of solid and liquid biofuels. $10.78 \%$ of total primary energy was generated from wind in 2015. Over the years 2011-2015, this way of generating energy grew mainly due to quite large amounts of EU funding.

It should be indicated that there are some doubts concerning the proper use of grants from public funds. EU subsidies for the energy sector are often not spent in accordance with original purposes. Public funding is said to support fossil fuels instead of RES investment projects that reduce greenhouse gas emissions (Caneurope.org, 2019).

\section{Analysis of the Possibilities of Development of the RES Sector}

As can be seen from the previous considerations, in the years 2011-2015 an increase in the share of renewable energy production in obtaining primary energy from $10.9 \%$ (in 2011) to $12.7 \%$ (in 2015) can be noted. Further development

Tab. 3:

The share of individual RES carriers in primary energy acquisition in 2011-2015 in Poland

\begin{tabular}{l|r|r|r|r|r}
\multicolumn{1}{r|}{ Type of RES } & $\mathbf{2 0 1 1}$ & $\mathbf{2 0 1 2}$ & $\mathbf{2 0 1 3}$ & $\mathbf{2 0 1 4}$ & $\mathbf{2 0 1 5}$ \\
\hline Solid biofuels & 84.89 & 82.07 & 79.88 & 76.14 & 72.22 \\
\hline Sun energy & 0.17 & 0.17 & 0.29 & 0.43 & 0.52 \\
\hline Water energy & 2.68 & 2.06 & 2.45 & 2.31 & 1.82 \\
\hline Wind energy & 3.68 & 4.79 & 6.03 & 8.13 & 10.76 \\
\hline Biogas & 1.83 & 1.97 & 2.12 & 2.56 & 2.64 \\
\hline Liquid biofuels & 5.76 & 7.96 & 8.18 & 9.18 & 10.78 \\
\hline Geothermal energy & 0.17 & 0.19 & 0.22 & 0.25 & 0.25 \\
\hline Municipal waste & 0.43 & 0.38 & 0.39 & 0.45 & 0.46 \\
\hline Heat pumps & 0.39 & 0.41 & 0.44 & 0.55 & 0.56 \\
\hline
\end{tabular}




\section{Fig. 1: Model of conditions for RES sector development in Poland}

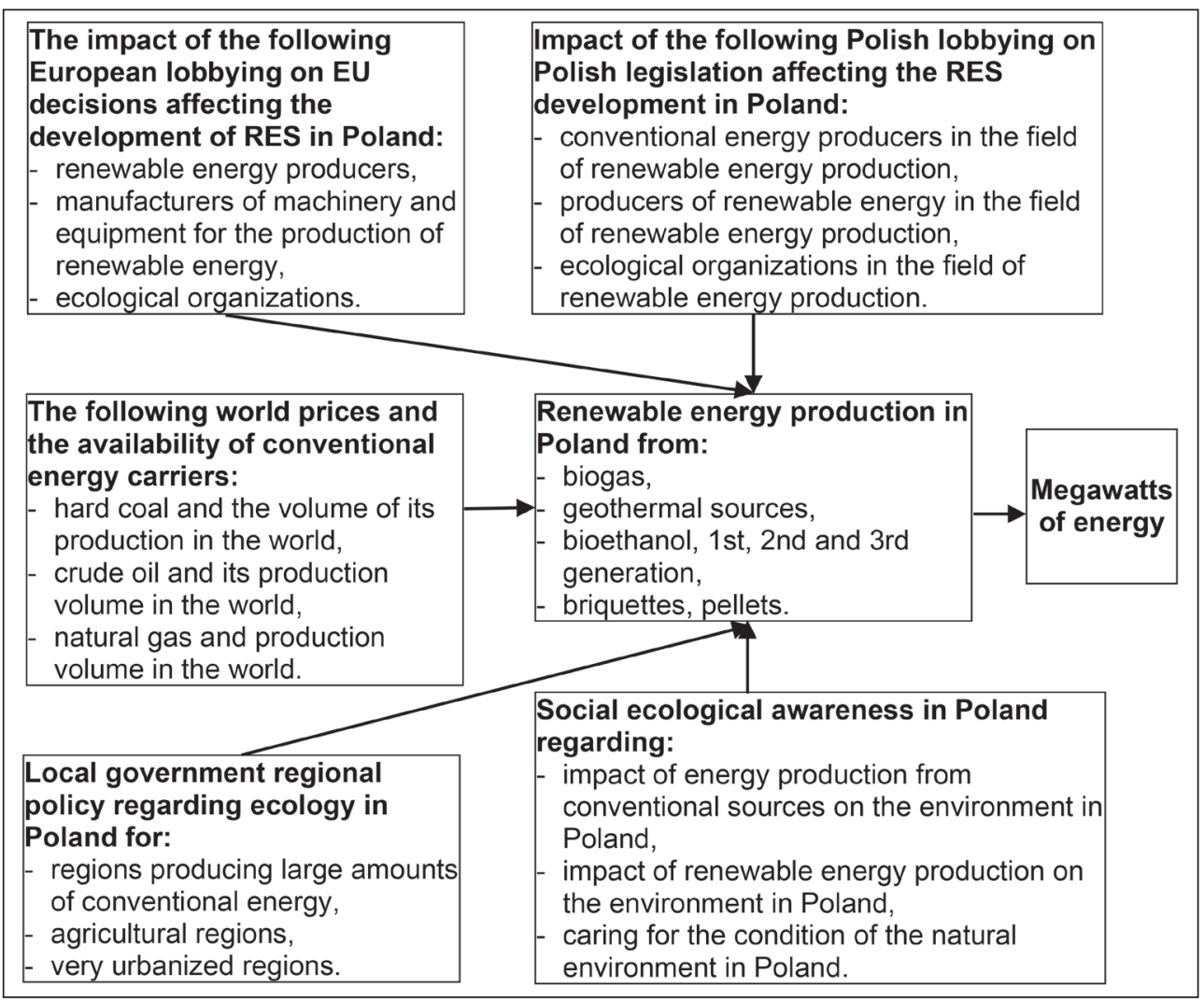

Source: own

of the RES sector in Poland depends on many economic, political and social factors. The basic ones determining the increase of energy production from RES may be appropriate decisions and strategic priorities of the EU affecting the development of RES sector, state legislation influencing the development of this sector, prices and availability of conventional energy carriers, regional policy on ecology in Poland and environmental awareness in this country.

As it results from the model of conditions of renewable energy production in Poland presented in Fig. 1, the basic conditions determining the development of renewable energy have been divided into factors that can be precisely examined and analyzed using the methodology characterized in the next point of this paper. Both the identification process and determined factors may vary to some extent from those presented in other literature positions because economic conditions of development of different EU countries vary (Remeikiene et al., 2020). The key to achieving climate neutrality thanks to the development of RES is taking into account the economic and demographic potentials of individual EU countries, their areas in specific geographic locations, as well as achieving social acceptability by individual countries for the proposed climate policy (Brodny \& Tutak, 2020). It is also important to properly concentrate the financing of European, public and development projects, to ensure adequate public investment, to support private research and development projects aimed at achieving Europe's 2030 
energy transition goals (Bointner et al., 2016). Some complementary sources of inspiration in this field may also be the results of research related to non-EU countries. In particular, it may be interesting to identify various groups of factors in three exemplary countries. In Russia, one can take into account e.g. economic, technical and technological factors (Gibadullin et al., 2020), while in China factors concerning technological innovation to renewables ( $\mathrm{He}$ et al., 2018) and in Turkey - factors taking into consideration the impact of e.g. population, natural gas prices and carbon emissions in this country (Yuksel \& Ubay, 2020).

Based on an in-depth review of the literature, Can Şener et al. (2018) gives e.g. recommendations on determining drivers and barriers as well as the key factors of RES, which can help in understanding the basic problems related to the implementation of renewable energy. As a result of the research, it was found that social, economic and environmental factors are drivers, whereas technical potential, technological aspects, political and regulatory factors are characterized by undefined impact (they are not barriers and do not drive RES development). Additionally, for the analyzed period (from 1949 to 2013), no significant barriers to RES deployment were identified. The appropriate selection and validity of these factors is of great importance in the process of building the model of conditions for RES sector development.

\section{Research Methodology}

Expert-mathematical method is an effective way which enables to prioritize the importance of economic, social and political factors influencing the development of the RES sector in Poland. The method makes it possible to analyze and evaluate very different factors, and the results obtained from its use differ from those of other methods in the range of $6-8 \%$ (Gordon \& Helmer-Hirschberg, 1964). Hence, this method is applied for military, economic, agricultural as well as other scientific purposes (Izdebski, 2003).

Obtaining credible results involves carrying out research according to determined procedure in a method that comprises the following steps: organization of the assessment procedure, selection of experts, carrying out of research and processing of research results. A group of experts in accordance with the method requirements has to be composed of competent persons who have knowledge and experience in the field from which the problem is addressed. The choice of experts is based on the criteria discussed in detail in the literature (Izdebski et al., 2012; Schobl et al., 1988). Basic requirement is not less than five years' experience and minimum level of education, for example high school graduates. Apart from that, the qualitative characteristics of the group of experts can be determined using qualities as: competence, creativity, attitude to expertise, conformism, constructive thinking and selfcriticism. Expert competence is assessed on the basis of a competence coefficient, which is determined as follows (Jewłanow, 1981):

$$
K=\frac{1}{2}\left(K_{i}+K_{A}\right) \quad 0 \leq K \leq 1
$$

where: $K_{i}$ - informativeness factor (knowledge of a given issue); $K_{A}$ - argument factor. The informativeness coefficient is determined on the basis of an expert's self-assessment (from 0 to 10 points) multiplied by 0.1 . The argumentation factor is resolute by an interview with an expert, taking into account array values, as presented in Tab. 4.

According to the literature (Jewlanow, 1988), the value of $K_{A}$ equal to 1 is considered to be a high level of argument, the value 0.8 - medium, and 0.5 is considered to be a low level of argument. As a basic criterion for the selection of experts recognized seniority in the profession concerning the production of renewable energy not less than five years and stimulating position to solved problems and taking appropriate decisions.

Each of the experts participating in the research received a research questionnaire in which he could cross out any number of factors proposed for assessment by the researchers, as well as he could add his factors which he considered very important and which were not included in the questionnaire.

Experimentation in the expert-mathematical method is often based on the assessment provided by experts of many factors which determine problems. When these factors occur in large numbers, it is virtually impossible or very difficult to compare and assess them by experts. In such circumstances, it is suggested to use the method of factor tree analysis, which is based on ordering of factors in groups and 


\section{Tab. 4: Argument coefficient values}

\begin{tabular}{l|c|c|c}
\multicolumn{1}{c|}{$\begin{array}{c}\text { The degree of influence of the source } \\
\text { on the expert's view }\end{array}$} & $\begin{array}{c}\text { A } \\
\text { high }\end{array}$ & $\begin{array}{c}\text { B } \\
\text { medium }\end{array}$ & $\begin{array}{c}\text { C } \\
\text { low }\end{array}$ \\
\hline Theoretical knowledge of the issue & 0.3 & 0.2 & 0.1 \\
\hline Work experience & 0.5 & 0.4 & 0.2 \\
\hline Knowledge of national specialist literature & 0.05 & 0.05 & 0.05 \\
\hline Knowledge of foreign professional literature & 0.05 & 0.05 & 0.05 \\
\hline Intuition & 0.1 & 0.1 & 0.1 \\
\hline \multicolumn{4}{|c}{ Source: Jewlanow (1988) }
\end{tabular}

a separate evaluation of the groups of factors and the isolated assessment of the factors in each group. The solution used by the authors and some researchers in their study (Izdebski et al., 2012) greatly facilitated the experts' evaluation of factors, and the authors were able to process the information obtained.

To find out that the compatibility of experts is not accidental, the $\chi$-squared criterion is used. In addition, the compliance of experts is checked by means of a variance coefficient which is normalized for the purpose of the expert-mathematical method.

Due to the abundance of factors making it difficult to assess their significance, the idea of a factor tree analysis (Fig. 2), which distinguishes five groups of factors (Tab. 5) called level II factors has been introduced. According to the hierarchy structure tree of factors in each group of the level II, some factors were identified that influenced the group, and indirectly the main factor. It was assumed that the total impact of five groups of factors of the level II is $100 \%$.

A special research questionnaire had been developed with nine tables to which the experts entered the desired information and evaluation. The first three tables contain the characteristics of the expert and the renewable energy company he represents. The other tables show the factors on the second and third levels of the factor tree. Placing factors in tables arranged by topics allowed the experts to focus only on a particular group of parameters, which made it easier for them to assess their validity.

These tables have blank space for experts to input assessment of the magnitude of the impact of a given group and of the individual factors on the development opportunities of the RES sector in Poland. The parameters listed in the tables are evaluated by experts

\section{Fig. 2: Tree of factors influencing the development of the RES sector in Poland}

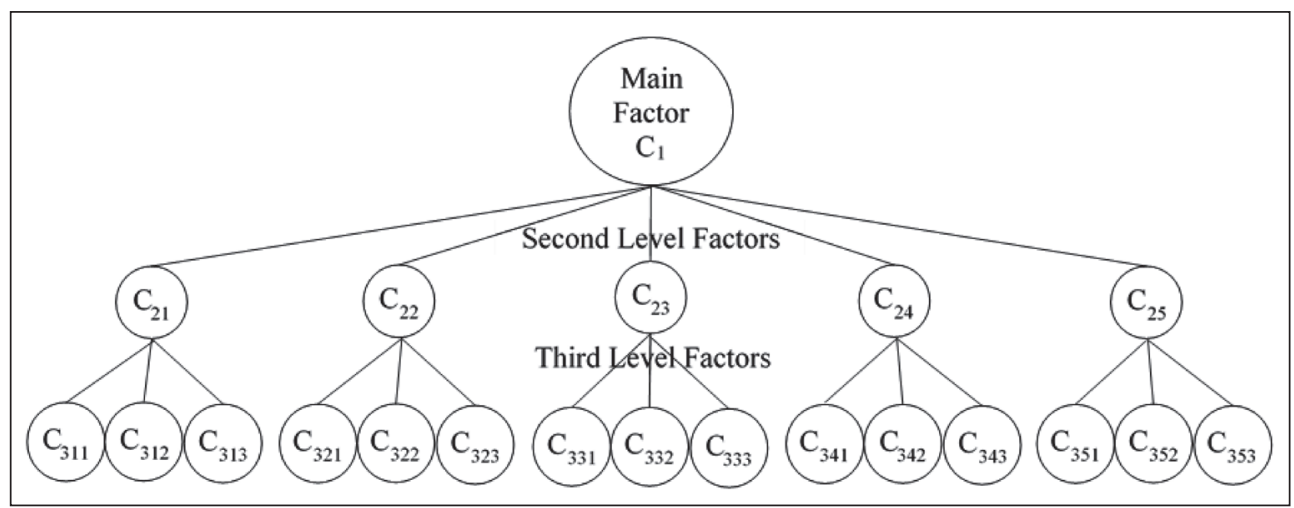


on a scale of 0 to 100 , so that the total of 100 points are allocated to all parameters. Assigning a parameter to an expert rating of 0 means that the parameter is not relevant to the expert. The number of points higher than zero reflect the importance of the parameter in relation to others.

In addition, the expert has the right to add and evaluate infinitely many other parameters that were not included in the tables and considered by him as important. The research questionnaire contains information that explain the expert how to assess the parameters, as well as given the telephone number and e-mail address required for the experts' contact with the authors when additional guidance and clarifications are needed.

A detailed study process includes, among others, mathematical identification of the minimum number of experts and their qualitative selection, as well as verifying the compliance of expert assessments using the following statistical methods (Jewłanow, 1988). The minimum number of experts required is determined by the dependence (2):

$$
N_{E}=\frac{f \beta(b-1)}{(\gamma+1)(b-1) \Theta 0},
$$

where: $f_{\beta}(b-1)$ - quantile distribution $\chi^{2}$ corresponding to confidence level $\beta$ and number of degrees of freedom $b-1 ; b$ - number of factors assessed; $\gamma$ - assumed accuracy in evaluation of concordance; $\Theta_{0}-$ critical value of the concordance coefficient.

The assessment of the local priorities of the assumed objectives set by the scaled scoring method (expressed in points or percentage) is slightly more complex than the prioritization by appropriate rankings. However, it is considerably advantageous because, as a result, one directly receives numerical values of priorities and their share in the overall structure of the factors under consideration. In this case, the compatibility of expert judgment is assessed using a variance coefficient.

Based on the expertise data, the local priority of the $m_{i j}$ factor is determined (3):

$$
m_{j}=\left(\sum_{i=1}^{N_{E}} m_{i j}\right) / N_{E},
$$

where: $m_{i j}$ - the normalized validity factor of the $j$-th factor determined by the $i$-th expert.
Then the mean square deviation of the significance factor of the $j$-th factor $(4,5)$ is determined:

$$
\begin{aligned}
& g_{j}=\sqrt{\frac{\sum_{i=1}^{N_{E}}\left(m_{j}-m_{i j}\right)^{2}}{N_{E}-1}} \text { for } N_{E} \leq 30, \\
& g_{j}=\sqrt{\frac{\sum_{i=1}^{N_{E}}\left(\bar{m}_{j}-m_{i j}\right)^{2}}{N_{E}}} \text { for } N_{E}>30 .
\end{aligned}
$$

Based on these indicators, the variance coefficient (6) is calculated for each factor:

$$
V_{j}=\frac{g_{j}}{\bar{m}_{j}} .
$$

It is believed that if $V_{j} \leq 0.25$, then the compliance of individual importance ratings assigned by experts is sufficient, while if $V_{j}>0.25$, then compliance is insufficient. The following gradation of variation coefficients can also be assumed: $V_{j} \leq 0.10$ - high compatibility; 0.10-0.25 - higher than average; 0.16-0.25 - average; 0.26-0.35 - lower than average; $V_{j}>0.35$ - low.

Discussion of other methods for calculating the number of experts, who experts who should participate in the panel, is presented in the paper (Ayre \& Scally, 2014).

\section{Results}

According to the adopted aim of this paper, expert research was carried out, in which the factors influencing development potential of the RES sector were assessed at two levels (level II -5 factors, level III - 15 factors) according to the factor tree analysis. This research is based on analysis of electricity production volumes using RES in Poland and in the EU in 2011-2014, identification of key factors influencing the development of this sector in Poland as well as analysis of the most important economic and social factors for the development of this sector.

In connection with the above the validity of 20 Level II and Level III factors are assessed. They are presented in the form of local priorities. According to the evaluation procedure, the parameters are divided into four validity 


\begin{tabular}{|c|c|}
\hline $\begin{array}{l}\text { Factor } \\
\text { label }\end{array}$ & Name of level III factor \\
\hline \multicolumn{2}{|c|}{ C 21 - European Union decisions affecting the development of the RES sector in Poland } \\
\hline C311 & Impact of European lobbying on renewable energy producers on EU law \\
\hline C312 & $\begin{array}{l}\text { Impact of European lobbying of manufacturers of machinery and equipment } \\
\text { for the production of renewable energy in EU law }\end{array}$ \\
\hline C313 & Impact of European organic lobbying on EU law \\
\hline \multicolumn{2}{|c|}{ C 22 - Polish legislation affecting the development of the RES sector in Poland } \\
\hline C321 & $\begin{array}{l}\text { Impact of Polish lobbying of conventional energy producers on Polish law } \\
\text { on renewable energy production }\end{array}$ \\
\hline C322 & $\begin{array}{l}\text { Impact of Polish lobbying of renewable energy producers on Polish law } \\
\text { on renewable energy production }\end{array}$ \\
\hline C323 & Impact of Polish environmental lobbying on Polish law on renewable energy production \\
\hline \multicolumn{2}{|r|}{ C 23 - Prices and availability of conventional energy sources } \\
\hline C331 & World hard coal prices and the volume of its output in the world \\
\hline C332 & World oil prices and its volume of its output in the world \\
\hline C333 & World prices of natural gas and the volume of its production in the world \\
\hline \multicolumn{2}{|r|}{ C $24-$ Regional policy on ecology in Poland } \\
\hline C341 & $\begin{array}{l}\text { Environmental policy of self-governments in regions producing large amounts } \\
\text { of conventional energy }\end{array}$ \\
\hline C342 & Environmental policy of self-governments in agricultural regions \\
\hline C343 & Environmental policy of self-governments in very urbanized regions \\
\hline \multicolumn{2}{|r|}{ C 25 - Environmental awareness in Poland } \\
\hline C351 & $\begin{array}{l}\text { Public awareness about the impact of conventional energy production } \\
\text { on the environment in Poland }\end{array}$ \\
\hline C352 & $\begin{array}{l}\text { Public awareness about the impact of renewable energy production } \\
\text { on the environment in Poland }\end{array}$ \\
\hline C353 & Public awareness about the care of the environment in Poland \\
\hline
\end{tabular}

intervals (high, higher than average, average, lower than average) to determine their weight and average values in the assumed intervals. Priority weights are determined by the degree of achievement of the main factor by a given group of parameters, which is in this range, and is determined by the sum of system priorities for those parameters.

At the end of the study, scores from 70 experts were received. The age of the experts ranged between 34 and 62, and the work experience in the power industry ranged from 9 to 41 years. The test included agricultural biogas plants and biogas plants in sewage treatment plants, which accounted for 19\%, wind farms (34\%), plants producing biomass energy carriers $(22 \%)$ and others $(27 \%)$.

Tabs. 6 and 7 show the mathematical parameters of the research results of the possibility of development of the RES sector in Poland.

The size of the system priorities of the level III factors is in the range of $1.3-17.7 \%$, the mean of one factor is $6.67 \%(100 \div 15=6.67)$. When dividing the system priority range into 4 groups and taking $6.67 \%$ as the mean, one can get the significance level of the individual factors: 1 - high (13.7-17.7), 2 - higher than average (9.6-13.6), 3 - medium (5.5-9.5), 4 - lower than the average (1.3-5.4). 


\begin{tabular}{|c|c|c|c|c|}
\hline Tab. 6: & Parameters concerning priorities of level II $\mathrm{f}$ & tors & & \\
\hline $\begin{array}{l}\text { Factor } \\
\text { label }\end{array}$ & Name of level II factor & $\begin{array}{l}\text { Priority } \\
\text { value }\end{array}$ & $\begin{array}{l}\text { Sum of } \\
\text { priorities }\end{array}$ & $\begin{array}{l}\text { Coefficient } \\
\text { of variation }\end{array}$ \\
\hline $\mathrm{C} 21$ & $\begin{array}{l}\text { EU decisions affecting the development of the RES } \\
\text { sector in Poland }\end{array}$ & 34.8 & 98 & 0.12 \\
\hline $\mathrm{C} 22$ & $\begin{array}{l}\text { Polish legislation affecting the development of the } \\
\text { RES sector in Poland }\end{array}$ & 24.0 & 154 & 0.16 \\
\hline $\mathrm{C} 23$ & $\begin{array}{l}\text { Prices and availability of conventional energy } \\
\text { carriers }\end{array}$ & 20.3 & 168 & 0.24 \\
\hline $\mathrm{C} 24$ & Regional policy on ecology in Poland & 6.5 & 364 & 0.12 \\
\hline $\mathrm{C} 25$ & Environmental awareness in Poland & 14.4 & 266 & 0.23 \\
\hline \multicolumn{2}{|r|}{ Coefficient of concordance } & \multicolumn{3}{|c|}{0.707} \\
\hline \multicolumn{2}{|r|}{$\chi^{2}$ criterion } & \multicolumn{3}{|c|}{48.78} \\
\hline
\end{tabular}

Source: own

\begin{tabular}{|c|c|c|c|c|}
\hline Tab. 7: & $\begin{array}{l}\text { The share of individual RES carriers in prime } \\
\text { in Poland - Part } 1\end{array}$ & energy & Equisitior & 2011-2015 \\
\hline $\begin{array}{l}\text { Factor } \\
\text { label }\end{array}$ & Name of level III factor & $\begin{array}{l}\text { Priority } \\
\text { value }\end{array}$ & $\begin{array}{c}\text { Sum of } \\
\text { priorities }\end{array}$ & $\begin{array}{l}\text { Coefficient } \\
\text { of variation }\end{array}$ \\
\hline C311 & $\begin{array}{l}\text { Impact of European lobbying on renewable energy } \\
\text { producers on EU law }\end{array}$ & 10.4 & 3 & 0.09 \\
\hline C312 & $\begin{array}{l}\text { Impact of European lobbying of manufacturers } \\
\text { of machinery and equipment for the production } \\
\text { of renewable energy in EU law }\end{array}$ & 17.3 & 1 & 0.13 \\
\hline C313 & Impact of European organic lobbying on EU law & 7.1 & 5 & 0.11 \\
\hline C321 & $\begin{array}{l}\text { Impact of Polish lobbying on conventional energy } \\
\text { producers on Polish law on renewable energy } \\
\text { production }\end{array}$ & 12.3 & 2 & 0.16 \\
\hline C322 & $\begin{array}{l}\text { Impact of Polish lobbying of renewable energy } \\
\text { producers on Polish law on renewable energy } \\
\text { production }\end{array}$ & 6.7 & 6 & 0.11 \\
\hline C323 & $\begin{array}{l}\text { Impact of Polish environmental lobbying on Polish } \\
\text { legislation on renewable energy production }\end{array}$ & 5.0 & 10 & 0.20 \\
\hline C331 & $\begin{array}{l}\text { World hard coal prices and the volume of its output } \\
\text { in the world }\end{array}$ & 8.4 & 4 & 0.13 \\
\hline C332 & $\begin{array}{l}\text { World oil prices and its volume of its output in the } \\
\text { world }\end{array}$ & 6.4 & 7 & 0.15 \\
\hline C333 & $\begin{array}{l}\text { World prices of natural gas and the volume of its } \\
\text { output in the world }\end{array}$ & 5.5 & 9 & 0.10 \\
\hline C341 & $\begin{array}{l}\text { Environmental policy of self-governments in regions } \\
\text { producing large amounts of conventional energy }\end{array}$ & 3.0 & 13 & 0.19 \\
\hline C342 & $\begin{array}{l}\text { Environmental policy of self-governments in } \\
\text { agricultural regions }\end{array}$ & 1.4 & 15 & 0.12 \\
\hline C343 & $\begin{array}{l}\text { Environmental policy of self-governments in very } \\
\text { urbanized regions }\end{array}$ & 2.3 & 14 & 0.17 \\
\hline
\end{tabular}




\section{Economics}

Tab. 7: $\begin{aligned} & \text { The share of individual RES carriers in primary energy acquisition in 2011-2015 } \\
& \text { in Poland - Part 2 }\end{aligned}$
\begin{tabular}{c|l|c|c|c} 
C351 & $\begin{array}{l}\text { Public awareness about the impact of conventional } \\
\text { energy production on the environment in Poland }\end{array}$ & 4.8 & 11 & 0.15 \\
\hline C352 & $\begin{array}{l}\text { Public awareness about the impact of renewable } \\
\text { energy production on the environment in Poland }\end{array}$ & 6.3 & 8 & 0.19 \\
\hline C353 & $\begin{array}{l}\text { Public awareness about the care of the environment } \\
\text { in Poland }\end{array}$ & 3.3 & 12 & 0.11 \\
\hline
\end{tabular}

Source: own

\begin{tabular}{|c|c|c|c|c|}
\hline $\begin{array}{c}\text { Range } \\
\text { no. }\end{array}$ & Range borders, $\%$ & $\begin{array}{l}\text { Labels of factors } \\
\text { entering the range }\end{array}$ & $\begin{array}{l}\text { Own weight } \\
\text { of the range, \% }\end{array}$ & $\begin{array}{c}\text { Average value } \\
\text { of system priority } \\
\text { factor in the range, } \%\end{array}$ \\
\hline 1 & $13.7-17.7$ & C312 & 17.1 & 17.1 \\
\hline 2 & $9.6-13.6$ & C321, C311 & 22.7 & 11.7 \\
\hline 3 & $5.5-9.5$ & $\begin{array}{l}\text { C331, C313, C322, } \\
\text { C332, C352, C333 }\end{array}$ & 40.4 & 6.7 \\
\hline 4 & $1.3-5.4$ & $\begin{array}{l}\text { C323, C351, C353, } \\
\text { C341, C343, C342 }\end{array}$ & 19.8 & 3.3 \\
\hline
\end{tabular}

Source: own

Tab. 8 shows that only one factor was reached in the high-relevancy range: $\mathrm{C} 312$, two were found in group 2; groups 3 and 4 had six factors. The third group has the highest own weight for the main factor in terms of average system priority. This group has so much 'own weight' only at the expense of a greater value of accumulated factors. The dependencies

\section{Fig. 3: Own weight and mean value of system level priorities}

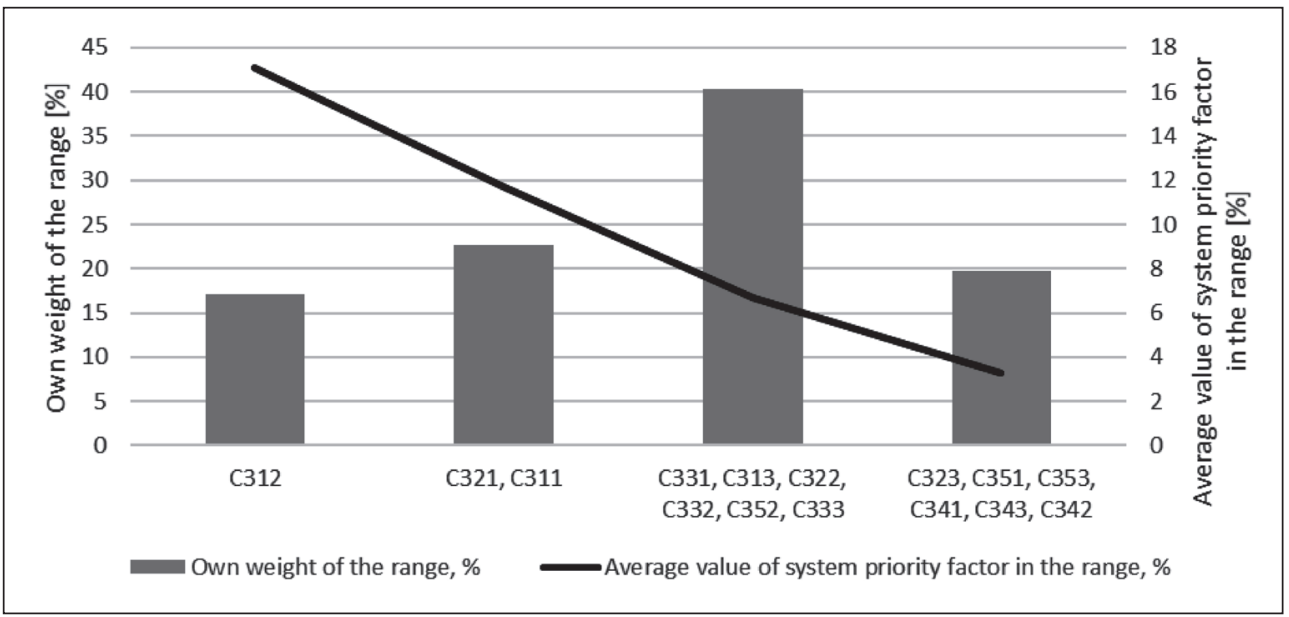


own weight of the range and average value of system priority factor in the range are presented in Fig. 3.

The development of the RES sector in Poland in the coming years will be influenced by the European lobbying of producers of machinery and equipment for the production of renewable energy to the law established by the EU. It should be noted that Polish and European lobbying on conventional and renewable energy producers on Polish and EU law will have significant influence on the development of RES sector in Poland. In the next part of the paper, the authors present a discussion mainly connected with the level II factors influencing the development of the RES sector in Poland.

\section{Discussion}

Discussion in this paper section is focused on the following issues:

- analysis of level II factors affecting the development of the RES sector;

- EU decisions influencing the development of the RES sector;

- Polish legislation affecting the development of the RES sector;

- prices and availability of conventional energy sources;

- regional policy on ecology;

- environmental awareness.

Considering the decisions of the EU that influence the development of the RES sector (34.8\% share in level II factors), the socalled Energy and Climate package shall be mentioned. This package refers to the following three key aspects: reducing $\mathrm{CO} 2$ emissions, promoting renewable energies and increasing the energy efficiency of EU countries. The package is a development of the 'Kyoto Protocol' which assumed that the regulations would reduce $\mathrm{CO} 2$ emissions by $20 \%$ (compared to 1990 levels), increase the share of renewable energy by $20 \%$ and the energy efficiency of member states by $20 \%$. Within the EU the share of biofuels in the transport balance will increase by $10 \%$.

According to Second Energy and Climate Package assumptions, the reduction of $\mathrm{CO} 2$ by 2030 is to be $40 \%$ (compared to 1990 gas emissions), renewable energy production is expected to be $27 \%$ of the total energy consumed in the EU. The third change pertains to the limitation of the so-called Trading $\mathrm{CO} 2$ Emissions. These entitlements are nothing more than the fee for emitting into the atmosphere a given amount of $\mathrm{CO} 2$ during the production of energy using coal and lignite (among others). A large volume of $\mathrm{CO} 2$ emission allowances is to be removed from the EU market, which will most likely lead to an increase in the charge for this type of emissions. In the opinion of the authors of this paper, the ratification of this Package could lead to an artificial increase in energy prices produced using carbonaceous fuels emitting large amounts of $\mathrm{CO} 2$. This will have economic consequences especially in the EU countries where most of the energy is produced using carbon sources, such as Poland (Turowski, 2017).

Polish legislation has a $24 \%$ share in the analyzed factors of level II. The most important Polish law regulating all issues related to renewable energy and also affecting the development of the RES sector in Poland is the Renewable Energy Sources Act (RES Act, 2015). Poland was obliged to ratify the socalled First and Second Climate and Energy Package to increase the amount of renewable energy produced and, consequently, to invest in renewable energy. Analyses show that the current share of renewable energy generation does not guarantee the assumed level of production in 2020 . This may be due to the fact that over the last few years mainly wind farms have received investments whose production capacity has been relatively low compared to the investment outlay.

Modifying and improving regulations can contribute to positive changes related to RES, motivating clients to electricity saving and reduction of energy consumption. It is necessary to introduce new energy regulations, because at present there are no relevant provisions regarding, e.g., the development of intelligent technologies, and the energy policy tools are used to a limited extent (Grycan, 2020).

The 2015 RES Act introduced a number of important changes to the legislation on renewable energy. The most important are changes to the funding support systems for renewable energy producers, which, according to different sources, are the ones most likely to lose out on wind power and benefit from cofiring. The authors of this paper believe that this seems to be a positive piece of information. As various reports indicate, the average cost of electricity production is lowest for multi-fuel combustion - co-firing of biomass with coal and 
for electricity generation using landfill gas - socalled biogas (Wisniewski et al., 2013). The price and availability of conventional energy sources has a $20.3 \%$ share in the analyzed level II factors. In 2015 and before, most of electricity in Poland was produced using fossil fuels, in particular coal and lignite. The amount of electricity produced by the coal- and lignitefired power plants was $83.73 \%$ (PSE Annual Report, 2015). Therefore, in this paper only the prices of coal as a conventional raw material used for the production of electricity are considered. Other conventional raw materials are omitted because their share in electricity production is very small.

Considering the prices of coal used for electricity production, it should be taken into consideration that the price of steam coal decreased systematically from 2012 as well as the price of $1 \mathrm{kWh}$ for the final consumer should also be systematically reduced (PSCMI, 2017). However, the final price consists not only of the production price of $1 \mathrm{kWh}$, but also: the cost of purchasing electricity, VAT, excise duties, fees and local taxes, distribution costs (dealer's own costs and margin) and industrial costs. Therefore, in the detailed analyzes of these factors, the average prices of electricity in each Polish region should be carefully assessed and, on that basis, appropriate conclusions should be drawn.

Regional policy on ecology has a $6.5 \%$ share in the analyzed factors of level II. The most important principle of ecological policy is the so-called Principle of sustainable development, a principle written in the Constitution of the Republic of Poland, which states that the essence of sustainable development is to treat economic, environmental and social reasons in the same way. In other words, it is about managing human resources economically and ecologically, to preserve environmental values in such a way as to ensure sustainable use by present and future generations (Sejm of the Republic of Poland, 2009).

The most important objectives of Poland's environmental policy (concerning the subject matter of this paper) are reduction of energy intensity of the economy (development of renewable energy in the field of electricity and heat production) and limiting the excavation of fossil fuels if a substitute for the energy carrier can be found. Implementing the goals of the adopted ecological policy requires adequate financial resources, much of which is financed by EU funds.

According to the Council of Ministers of the Republic of Poland (2008) concerning the regional policy, in which ecological obligations for the state were introduced are, for example: Poland's Energy Policy until 2030, National Reform Program and Energy Security and Environment strategy. Poland's Energy Policy until 2030 is a document, which contains the necessary directions for the development of the country's energy sector by 2030 . They include, among others, increasing the energy efficiency of Poland, improving security of energy and fuel supplies, diversification of electricity generation factors through the development of nuclear power, development of the RES sector energy (including biofuels), reducing the impact of the energy sector on the environment as well as development of competitive fuel and energy markets.

In the National Reform Program, among others, key actions aimed at increasing Poland's energy efficiency have been included. It highlights key investments, modernization and reconstruction of new and existing elements of Poland's energy infrastructure, aimed at achieving the goals of the Europe 2020 strategy (European Commission, 2010). The goal of the Energy Security and Environment strategy is the sustainable development of the energy sector, while improving the environment (Act, 2009). Polish legislation has a $14.4 \%$ share in analyzed factors of level II. Citizens' awareness of matters of national importance is one of the cornerstones of the functioning of the state, which also applies to ecological awareness. In order to achieve the goals in the context of energy policy, first and foremost, citizens should be provided with access to reliable information on the subject, and be ensured that their environmental education is adequate. According to research conducted at the request of the Ministry of Environmental Protection (TNS, 2015), there are quite big deficiencies in the society as regards the link between environmental protection and energy. The greatest lack of knowledge among citizens' concerns: RES (in the context of the details of their use), economic efficiency and productivity, nuclear power industry, energy saving at home and at work as well as use of smart energy meters. 


\section{Conclusions}

The level of production of renewable energy in Poland results from the relevant EU directives as well as from the rich resources of this kind of energy in the state, such as agricultural products as well as food and wood processing, waste, geothermal energy, sun, water and wind energy. This paper attempts to determine the possibilities of development of the RES sector. For this purpose, expert research was carried out in which factors influencing the development potential of this sector were assessed at two levels of their evaluation (with several factors) according to the factor tree analysis.

In response to the research questions, it can be stated: energy production from RES in the EU is clearly increasing. Its share in obtaining primary energy is from $20.1 \%$ in 2010 to $25.4 \%$ in 2014 , and in Poland this increase is less noticeable - from $10.2 \%$ in 2010 to $11.9 \%$ in 2014. The acquisition of primary energy in Poland is changing, but in principle remains at a similar level - from 67.5 Mtoe in 2010 to 71.8 Mtoe in 2013, then fell to 68.2 Mtoe in 2014.

Achieving a state of significant dependence on RES and the use of the extreme cases, which are even based on renewable self-sufficiency, is unreal and prohibitively expensive even in countries such as Great Britain and Germany (Green \& Staffell, 2017). All the more, it is not possible in Poland, however, one should think about the possibilities of improving the situation in this area.

Based on the analysis of the level II factors, it can be concluded that the development of the RES sector will depend to a decisive extent on three factors such as: EU decisions affecting the development of the RES sector (34.8\% share), Polish legislation having an impact on the development of the RES sector $(24.0 \%$ share) as well as prices and availability of conventional energy carriers $(20.3 \%$ share). The other two factors - regional policy on ecology and environmental awareness - have so far little impact on the development of this sector in the state, and their total share is $20.9 \%$.

The analysis of the level III factors shows that the greatest impact on the development of the RES sector is the impact of European lobbying of producers of machinery and equipment for renewable energy production on EU law (17.1\% share of the level III factors), the impact of Polish producers lobbying conventional energy on Polish law in the field of renewable energy production (12.3\% share) and the impact of European lobbying of renewable energy producers on EU law (10.4\% share). The remaining twelve level III factors have a combined share of $60.2 \%$, which on average gives a $7.6 \%$ share among factors of the level III group.

Based on the detailed analysis of the factors of significance level II carried out in this paper, it can be concluded that there are great opportunities for the development of the RES sector, in which the policy of the EU and Polish legislation will play a significant role. The conducted research shows that in this development too small role is played by the policy of local governments as well as by ecological awareness of Polish society, which in the near future should be changed.

Several postulates regarding legal regulations related to RES can be formulated. Firstly, RES sector regulations should be a clear source of information and guidelines useful for organizations interested in investing in this area. Thanks to the logical and pragmatic presentation of these issues, potential investors may be aware of the risk of planned and implemented energy projects. Secondly, the planned and implemented energy policy, depending on the adopted variant of activities, creates a greater or lesser threat to the natural environment and people. Therefore, the choice of a particular policy and its implementation cannot take place without obtaining public acceptance, let alone against public opinion. Finally, it is necessary to introduce greater preferences for the development of small power industry: small hydro, wind and other power plants as well as power devices built by small enterprises or private individuals. These preferences should also apply to companies wishing to produce equipment for the construction of such installations.

This paper is one the first such analyzes of socio-economic conditions for the development of the RES sector in Poland. It is useful for the development of further research related to the identification of socio-economic factors influencing the development of the RES sector in other European countries. Future research may also be inspired by challenges related to the necessary regulation of electricity markets and integration of RES variable. European electricity and the RES sector are characterized by institutional fragmentation, 
and the specificity and developmental variability of this sector require the implementation of better coordination between countries that have different levels of power systems and different time scales (De Vries \& Verzijlbergh, 2018).

The main research limitation in this paper is the number of factors examined affecting the development of RES - too many of them could significantly interfere with the possibility of their correct assessment by experts. The authors are planning their next study, in which they will take further factors for analysis, such as: R\&D expenditures, raw materials and climate. The future research could include the previous conclusions concerning the identification of socio-economic factors described by other scientists and academics in their publications.

\section{References}

Act. (2009). Act of 6 December 2006 on the Rules for Conducting Development Policy. Dz.U. 2006, No. 227 item 1658, with later change (Dz.U. of 2009, No 84, item 712 and No 157, item 1241).

Ayre, C., \& Scally, A. J. (2014). Critical Values for Lawshe's Content Validity Ratio: Revisiting the Original Methods of Calculation. Measurement and Evaluation in Counseling and Development, 47(1), 79-86. https://doi. org/10.1177/0748175613513808

Bointner, R., Pezzutto, S., Grilli, G., \& Sparber, W. (2016). Financing Innovations for the Renewable Energy Transition in Europe. Energies, 9(12), 990. https://doi.org/10.3390/en9120990

Brodny, J., \& Tutak, M. (2020). Analyzing Similarities between the European Union Countries in Terms of the Structure and Volume of Energy Production from Renewable Energy Sources. Energies, 13(4), 913. https://doi. org/10.3390/en13040913

Brundtland, G. (1987). Report of the World Commission on Environment and Development: Our Common Future. Retrieved August 20, 2019, from http://www.un-documents.net/ourcommon-future.pdf

Can Şener, S. E., Sharp, J. L., \& Anctil, A. (2018). Factors impacting diverging paths of renewable energy: A review. Renewable and Sustainable Energy Reviews, 81(2), 2335-2342. https://doi.org/10.1016/j.rser.2017.06.042

Caneurope.org. (2019). The 2018 European Fossil Fuel Subsidies Awards. Retrieved August 20, 2019, from www.caneurope.org/fossil-fuelsubsidies-awards\#intro
Central Statistical Office. (2015). GUS Report: Energy from renewable sources in 2015. Retrieved April 30, 2018, from http:// stat.gov.pl/download/gfx/portalinformacyjny/pl/ defaultaktualnosci/5485/3/10/1/energia_ze_ zrodel_odnawialnych_w_2015_roku.pdf

Council of Ministers Republic of Poland. (2008). The National Environmental Policy 2009-2012 and its 2016 outlook. Ministry of Environment Republic of Poland. Retrieved March 03, 2018, from www.me.gov.pl/files/ upload/26986/ListaProjektowStratecznych dlainfrastrukturyenergetycznej.pdf

De Vries, L. J., \& Verzijlbergh, R. A. (2018). How Renewable Energy is Reshaping Europe's Electricity Market Design. Economics of Energy \& Environmental Policy, 7(2), 31-49. https://doi. org/10.5547/2160-5890.7.2.Idev

Duscha, V., Fougeyrollas, A., Nathani, C., Pfaff, M., Ragwitz, M., Resch, G., Schade, W., Breitschopf, B., \& Walz, R. (2016). Renewable energy deployment in Europe up to 2030 and the aim of a triple dividend. Energy Policy, 95, 314-323. https://doi.org/10.1016/j. enpol.2016.05.011

EMBER. (2020). Renewables beat fossil fuels. A half-yearly analysis of Europe's electricity transition. Retrieved July 24, 2020, from https://ember-climate.org/project/renewablesbeat-fossil-fuels

European Commission. (2010). Europe 2020: A strategy for smart, sustainable and inclusive growth. Communication from the Commission, COM(2010). Retrieved August 21, 2019, from https://ec.europa.eu/eu2020/pdf/COMPLET\%20 EN\%20BARROSO $\% 20 \% 20 \% 20007 \% 20-\% 20$ Europe\%202020\%20-\%20EN\%20version.pdf

European Commission. (2012). Roadmap 2050. Policy 1-9. Communication from the Commission to the European Parliament, the Council, the European Economic and Social Committee and the Committee of the Regions, $\operatorname{COM}(2011), 885 / 2$. https://doi. org/10.2833/10759

European Council. (2020). Special meeting of the European Council (17, 18, 19, 20 and 21 July 2020) - Conclusions. Brussels: European Council. Retrieved July 24, 2020, from https://www.consilium.europa.eu/media/ 45109/210720-euco-final-conclusions-en.pdf

Gibadullin, A., Sadriddinov, M., Kurbonova, Z., Shedko, Y., \& Shamraeva, V. (2020). Assessment of factors ensuring sustainable development of the electric power industry 
in the context of transition to renewable energy sources of the national economy. IOP Conference Series: Earth and Environmental Science, 421(3). https://doi.org/10.1088/17551315/421/3/032051

Gordon, T. J., \& Helmer-Hirschberg, O. (1964). Report on a Long-Range Forecasting Study (Working paper P-2982). Santa Monica, CA: RAND Corporation. Retrieved June 05, 2020, from https://www.rand.org/pubs/papers/ P2982.html

Green, R., \& Staffell, I. (2017). Prosumage and the British Electricity Market. Economics of Energy \& Environmental Policy, 6(1), 33-49. https://doi.org/10.5547/2160-5890.6.1.rgre

Grycan, W. (2020). Legislative support for improving sustainable and smart electricity consumption in polish residential sector. Journal of Cleaner Production, 266, 121995. https://doi. org/10.1016/j.jclepro.2020.121995

He, Z. X., Xu, S. C., Li, Q. B., \& Zhao, B. (2018). Factors that influence renewable energy technological innovation in China: A dynamic panel approach. Sustainability, 10(1), 124. https://doi.org/10.3390/su10010124

Izdebski, W. (2003). Strategie wyposażenia gospodarstw rolnych $w$ kombajny zbożowe [Strategies for equipping farms with combine harvesters] (Scientific dissertations and monographs, 273). Warsaw: Warsaw University of Life Sciences.

Izdebski, W., Skudlarski, J., \& Zajac, S. (2012). Analysis of the significance of technological and organizational factors affecting the efficiency of agricultural tractors operation. Teka, Commission of Motorization and Energetics in Agriculture, 12(1), 323-329.

Jewlanow, L. G., \& Kutuzow, W. A. (1988). Ekspertne ocenki w uprawlenii. Ekonomika, 3.

Karplus, V. J., \& Von Hirschhausen, C. (2019). Electricity Access: An Introduction. Economics of Energy \& Environmental Policy, 8(1).

Myšáková, D., Jáč, I., \& Petrů, M. (2016). Investment Opportunities for Family Businesses in the Field of Use of Biogas Plants. E\&M Economics and Management, 19(4), 19-32. https://doi.org/10.15240/tul/001/2016-4-002

Nilsson, L. J., Pisarek, M., Buriak, J., Oniszk-Popławska, A., Bućko, P., Ericsson, K., \& Jaworski, L. (2006). Energy policy and the role of bioenergy in Poland. Energy Policy, 34(15), 2263-2278. https://doi.org/10.1016/j. enpol.2005.03.011
PSCMI. (2017). Polish Steam Coal Market Index 1. Retrieved April 24, 2019, from www. polskirynekwegla.pl/o-indeksie

PSE. (2015). Polish Power System (Annual Report). Retrieved April 04, 2019, from http://www.pse.pl/uploads/kontener/Raport_ Roczny_2015.pdf

Quintana-Rojo, C., Callejas-Albiñana, F.E., Tarancón, M.-A., \& Martinez-Rodríguez, I. (2020). Econometric Studies on the Development of Renewable Energy Sources to Support the European Union 2020-2030 Climate and Energy Framework: A Critical Appraisal. Sustainability, 12(12), 4828. https://doi.org/10.3390/su12124828

RES Act. (2015). Renewable Energy Sources Act of 20 February 2015. Retrieved August 19, 2019, from https://www. nortonrosefulbright.com/en/knowledge/publica tions/805b0af8/the-renewable-energy-sourcesact

Remeikiene, R., Belas, J., Kliestik, T., \& Smrcka, L. (2020). Quantitative assessment of dynamics of economic development in the countries of the European Union. Technological and Economic Development of Economy, 26(4), 933-946. https://doi.org/10.3846/ tede.2020.12892

Schobl, R., Blobel, R., \& Schlorf, U. (1988). Betriebswirtschaftliche Regelungen zur Verlangerung der Nutzungsdauer der technik. Kooperation, 22(5).

Sejm of the Republic of Poland. (2009). Resolution of the Sejm of the Republic of Poland of 22 May 2009 on adoption of the document "National Environmental Policy in 2009-2012 with Prospects until 2016". M.P. of 4 June 2009, no 34, item 501.

Siksnelyte, I., Zavadskas, E. K., Bausys, R., \& Streimikiene, D. (2019). Implementation of EU energy policy priorities in the Baltic Sea Region countries: Sustainability assessment based on neutrosophic MULTIMOORA method. Energy Policy, 125(C), 90-102. https://doi. org/10.1016/j.enpol.2018.10.013

Spencer, T., Pierfederici, R., Sartor, O., Berghmans, N., Samadi, S., Fischedick, M., Knoop, K., Pye, S., Criqui, P., Mathy, S., \& Capros, P. (2017). Tracking sectoral progress in the deep decarbonisation of energy systems in Europe. Energy Policy, 110(C), 509-517. https://doi.org/10.1016/j.enpol.2017.08.053

Štreimikienè, D., \& Mikalauskienè, A. (2016). Green Growth and Use of EU Structural Funds 
in Baltic States, Czech Republic and Slovakia. E\&M Economics and Management, 19(2), 55-72. https://doi.org/10.15240/tul/001/2016-2-004

TNS. (2015). Raport $z$ analizy badań świadomości, postaw i zachowań ekologicznych Polaków przeprowadzonych w Polsce w latach 2009-2015, Analiza TNS Polska dla Ministerstwa Środowiska [The report on the analysis of the surveys on ecological awareness, attitudes and behaviour of Poles conducted in Poland in 2009-2015, prepared for the Ministry of the Environment by the TNS Polska]. Retrieved April 30, 2019, from www.3xsrodowisko.pl/uploads/media/badanie_ dr_ekologia_ministerstwo_srodowiska.pdf

Turowski, P. (2014). Ochrona klimatu czy gra interesów? Drugi pakiet klimatycznoenergetyczny UE [Climate protection or a game of interests? The second EU climate and energy package]. Bezpieczeństwo Narodowe, III-2014. Retrieved May 5, 2019, from https://www.bbn. gov.pl/ftp/dok/73-92\%20turowski.pdf

United Nations. (2015). Transforming our World: The 2030 Agenda for Sustainable Development, A/RES/70/1. Retrieved August 20, 2019, from https://sustainabledevelopment. un.org/content/documents/21252030\%20Agen da\%20for\%20Sustainable\%20Development $\% 20$ web.pdf
United Nations. (2019). The Sustainable Development Goals Report. Retrieved August 18, 2019, from https://unstats.un.org/sdgs/ report/2019/The-Sustainable-DevelopmentGoals-Report-2019.pdf

Wiśniewski, G., Dziamski, P., Kunikowski, G., Ligus, M., Curkowski, A., MichałowskaKnap, K., Rosołek, K., Oniszk-Popławska, A., Więcka, A., \& Mroszkiewicz, T. (2013). Analiza dotycząca możliwości określenia niezbędnej wysokości wsparcia dla poszczególnych technologii OZE $w$ kontekście realizacji 'Krajowego planu działania w zakresie energii ze źródeł odnawialnych' [Analysis regarding the possibility of determining the necessary amount of support for individual RES technologies in the context of the implementation of the 'National Action Plan for Renewable Energy']. Warszawa: Institute for Renewable Energy. Retrieved April 30, 2019, from http://ieo.pl/pl/raporty/72--25/file

Yuksel, S., \& Ubay, G. G. (2020). Identifying the influencing factors of renewable energy consumption in Turkey with MARS methodology. Ekonomi Isletme ve Maliye Arastırmaları Dergisi, 2(1), 1-14. https://doi. org/10.38009/ekimad.694300 